\title{
Firms Financial Performance and Human Resource Accounting Disclosure in Nigeria
}

\author{
Leyira Christian Micah ${ }^{1}$, Clifford O. Ofurum ${ }^{1} \&$ John U. Ihendinihu ${ }^{2}$ \\ ${ }^{1}$ Department of Accounting, Faculty of Management Sciences, University of Port Harcourt, Rivers State, \\ Nigeria \\ ${ }^{2}$ Michael Okpara University of Agriculture, Omudike, Abia State, Nigeria \\ Correspondence: Leyira Christian Micah, Department of Accounting, Faculty of Management Sciences, \\ University of Port Harcourt, Rivers State, Nigeria. Tel: 234-803-354-2244. E-mail: leyimic@yahoo.com
}

Received: April 05, 2012 Accepted: May 31, 2012 Online Published: July 16, 2012

doi:10.5539/ijbm.v7n14p67 URL: http://dx.doi.org/10.5539/ijbm.v7n14p67

\begin{abstract}
The purpose of this study was to examine the relationship between firms financial performance and human resource accounting disclosure of companies in Nigeria. Five years financial data from 2005-2009 of fifty two companies across all sectors as listed on the Nigeria stock exchange fact book of 2005-2009 were extracted using simple random sampling techniques. Descriptive, correlation and regression statistical techniques were used in analyzing the data. Our findings show that the combined effect of Firm Financial Performance accounted for $75.9 \%$ of the variation in Human Resource Accounting Disclosure (HRAD) with an F- ratio 3.581 being significant at 5\% confidence level. The positive correlation between Return on Equity (ROE) and Human Resource Accounting Disclosure (HRAD) supposes that an increase in return on equity encourage firm in reporting human capital information so as to establish trustworthiness with stakeholders; enhance external reputation, appear legitimate in the public eye and avoid cost for non legitimacy. The study concludes that human resource accounting information of an organization is very important factor for decision makers in an era of knowledge based economy. There is growing evidence of the interest and demand among stakeholders for information from firm in relation to human capital. Based on this, the study recommended among others, regulatory intervention in the accounting standard setting process for human capital reporting in Nigeria. Standard should be created for human resource identification and measurement. This will enhance valuation of human capital, ensure a higher degree of utility to stakeholder, uniformity in disclosures and will allow reliable comparison of human capital values.
\end{abstract}

Keywords: human resource accounting, disclosure, intellectual capital

\section{Introduction}

Human Resources (HR) are the energies, skills, talents and knowledge of people which are, or which potentially can be applied to the production of goods or rendering useful services. HRA is the process of identifying and measuring data about human resources and communicating this information to interested parties. Human resource accounting is not a new issue in economics. Economists consider human capital as a production factor, and they explore different ways of measuring its investment in education, health, and other areas.

\subsection{Statement of the Problem}

According to Sveiby (1997), human capital, intellectual capital and structural capital concepts are similar to other assets. He also argued that organizations acquire Human Resources to generate future revenues, and therefore Human Resource should be considered when valuing a company by capitalizing instead of expensing them in the current period. Human resources is largely seen as an integral part of the firm's value - creating processes (Pike et al 2000, Holland, 2003; Bukh et al, 2005, OECD, 2006) as well as creating and maintaining competitive advantage (Holland, 2006). In today's dynamic business environment, firms invest heavily in human capital assets. The problem however, is that these investments are either immediately expensed in the financial statement or arbitrarily armotised and therefore are not fully reflected in the balance sheet. Consequently, the book values of firms with significant amounts of human capital investments are unrelated to the market values (Amir and Lev, 1996; Brennan, 2001; Lev, 2001; Holland, 2003). 
In Nigeria for instance, in 2006 Unilever invested over N40 million in training its employees, besides in house programmes to develop staff, and mutual expatiation of employees in Sister companies abroad (Annual Report 2008). As far back as 1988, Nigerian Breweries plc invested more than N88 million in local and overseas training of staff. Access Bank Plc in 2007 commenced construction of Access Bank Campus otherwise called Access University of Banking Excellence. Wema Bank plc has a policy of sending each staff to relevant training for at least 80 hours in each financial year. These heavy investments to train and retrain quality staff are not reflected in the balance sheet of these various organizations. Indeed, they are charged against revenue for the period to reduce income and by extension the value of the business.

Thus currently, the information of human capital is not properly presented on balance sheets or other traditional financial records since no regulations need to be met. This is also due to strict recognition criteria for intangible assets that do not allow human resources to be shown as an asset in the balance sheet (Tayles et al 2002).

Our purpose of this study is to find the levels of HRA disclosure in the listed companies in Nigeria and determine if management disclosure level of human capital was influenced by firm financial performance.

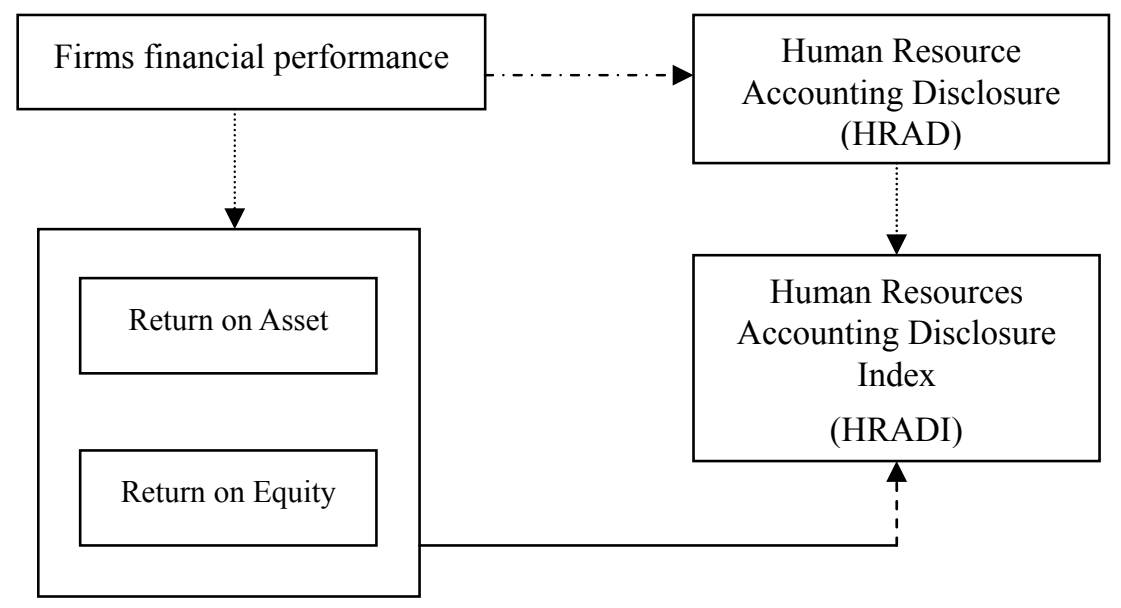

Figure 1. Conceptual model

\subsection{Hypotheses}

Therefore, the following hypotheses are tested:

$\mathrm{H}_{1}$ : There is no significant relationship between Return on asset (ROA) and Human Resource Accounting Disclosure (HRAD).

$\mathrm{HO}_{2}$ : There is no significant relationship between Return on Equity (ROE) and Human Resource Accounting Disclosure.

$\mathrm{HO}_{3}$ : Firm performance has no significant relationship with HRAD.

\section{Theoretical Framework and Literature Review}

In the economics literature, human capital refers to the productive capabilities of people (Becker 1964). Skills, experience, and knowledge have economic value to organizations because they enable it to be productive and adaptable. Thus, people constitute the organization's human capital (Bassey and Arzizeh, 2012).

However, there have been controversial issues of human capital reporting on whether it is value relevant to be considered as asset, even though its association with company's expected future benefits is not certain. Some group considered it as what people owned from learning, experience and skill while another group delineated it as human capability that is directly linked to the work (AL Maani and Jeradat, 2010). Few studies on value relevance of intellectual (human) capital assets include Guthrie, 2001; Amir and Lev 1996; Barth, Beaver, and Landsman, 2001; Aboody and Lev, 1998; Kohlbeck, 2004; Okwy and Christopher 2010.

The chartered institute of management accountants noted that all drivers of performance and value should be provided to investors including the non financial ones such as intangibles (Starovic \&Marr, 2003). The financial Accounting Standard Board addressed this issue by encouraging business to voluntarily disclose information regarding their intangibles and intellectual capital (FASB 2001). 
Recent emphasis on intellectual capital (IC) and Human capital disclosure can be attributed partly to the increased interest on enhancing voluntary corporate disclosure of non-financial information (AICPA 1994; Bjurstrom, Catasus \& Jorlusury, 2003; CICA, 1995; DMSTI, 2003a; DMSTI, 2003b; FASB, 2001; IASB, 2000; Meritum, 2002; Wallman, 1995; Wallman 1996.) Some companies in Europe produce a separate IC statement as a supplement to their annual report or as a separate report.

In Nigeria, the companies and allied matters Act sets the general framework for financial accounting and reporting by registered companies and stipulates the basic maximum requirements with regard to financial reporting. Because of the limited details of the Act, financial reporting and regulation is supplemented by the Nigerian Accounting standard Board (NASB). Nigeria issued its first accounting standard (SAS No. 22) on intangible assets only in June 2006. Before then, Nigeria did not have accounting standard on intangible asset (Mohammad and Salomon, 2011). Despite the fact that SAS No. 22 is directly related to intellectual capital driver human capital are treated as expenses in the income statement in Nigeria.

The relatively low importance placed on HC information by preparers and user of business reports can be attributed to the way $\mathrm{HC}$ is conceptualized and subsequently operationalized in intellectual capital disclosure studies. Sveiby (1997) conceptualization of employee competence as the stock of knowledge embodied in the organization's people has strong links with human capital theory.

According to HC Theory, an individual skills, experience and knowledge generate economic value (Coff, 1997).

Corporate performance and society's expectation change in different directions, or in the same direction but with differing momentum (Wartick and Mahon, 1994). Intellectual capital resources (including human capital) are increasingly important factors on the successful achievement of organizational objectives (Guthrie and Petty, 2000). For stakeholders to fully understand an organization and the effectiveness of its managers, it is therefore important that corporate reports adequately reflect all resources used and developed to further the organization's achievement (Boedker et al (2005). Nigeria which has plans to move up the value chain for certain high growth industries has to build up its human resources to be more competitive in a globalize world. That is the reason why human capital investment is becoming important agenda in many companies nowadays. The reporting of these corporate activities in annual reports may indicate that the firms were responsible corporate citizen, with the aim to provide accurate and transparent reporting.

Williams (2001) predicted that a positive relationship exists between a firm's level of performance and its level of intellectual disclosure. Contrary to the prediction, the researcher found a statistically significant inverse relationship between the level of a firm's intellectual capital disclosure and its level of performance. Based on the results of their study they reasoned that once a firm reaches a certain level of performance, it may reduce its level of disclosure to conceal from competitors strategically significant information in an effort to maintain its competitive advantage. Syed (2009) examined the relationship between corporate characteristics and HRA disclosure. The study indicates that companies with higher profitability intended to disclose more HRA information. A good financial position intensifies the credibility of information released by a company (Hughes, 1986; Scott, 1994; Beaner, 1989). As a result of the increased credibility the value of the firm is enhanced (Clarkson and Simumic, 1994; Cormier and Magnan, 2000). Credibility of information disclosed adds to the value of the enterprise as the details released assists in reducing the risk associated with an investor's decision making process. This supposes that if human capital is not reported, there is a risk that it is not receiving sufficient attention from management and other stakeholders (Guthrie and Petty, 2000), thereby diluting firm's value. To remove this difficulty and get shareholder's attention, many companies are now reporting on their human resources in a mostly non financial format in the annual reports voluntarily.

\section{Methodology}

Given the large number of publicly listed companies in Nigeria, it was further decided to limit the sample population to those firms continuously listed on the NSE between December 31, 2005 and December 31, 2009. The sample size consisted of fifty two (52) listed firms randomly drawn from all sectors in Nigeria.

In this study, human resource accounting disclosure (HRAD) was measured by constructing an index comprising fifteen (15) discretionary human capital disclosure items in line with the methodology adopted by kellonway and Barring (2000) and Syed (2009).

An HRADI shall be computed by using the following formula.

HRADI $=$ Total score of Individual company X 100

Maximum possible score obtainable 
Table 1. Measurement of HRAD variables

\begin{tabular}{ll}
\hline No & Disclosure Items \\
\hline 1 & Separate HRA statement \\
2 & Total value of Human Resource (cost of HR maintenance) \\
3 & Number of Employees \\
4 & Human resource policy \\
5 & Training \& development \\
6 & Management succession plan \\
7 & Employment Report \\
8 & Employee's value creation \\
9 & Human Resource development fund \\
10 & Employees/workers fund \\
11 & Employee categories \\
12 & Managerial remuneration \\
13 & Retirement benefits \\
14 & Performance Recognition \\
15 & Pension fund \\
\hline
\end{tabular}

Source: Syed 2009.

Return on Asset (ROA) is measured as Profit before Tax/Average Total Assets. ROA is a measure of profitability that takes into consideration the assets necessary to produce income.

Return on Equity (ROE) is measured as Profit before Tax/ Average common stock (Equity). Of course, stockholders are interested in how much they have earned on their investment in the business.

Descriptive statistics in the form of tables, percentages were used to present demographic and other data relating to the study.

Multiple Regressions was used to analyze the possible relationship between firm financial performance and Human resource Accounting Disclosure in Nigeria, using the statistical package for social science (SPSS) version 17.0. The strength of the relationship between the Independent and dependent variable were ascertained by using Pearson Product moment correlation coefficient "r".

Model Specification

$$
H R A D=f(R O A, R O E)
$$

Expressing equation (1) in explicit form, we have

$$
H R A D=a 0+b 1 R O A+b 2 R O E+e t
$$

$\mathrm{b} 1>0$; $\mathrm{b} 2>0$;

Where

HRADI = Human Resource Accounting Disclosure Index

$\mathrm{a} 0=$ Intercept of the regression line

$\mathrm{b}=$ Coefficient (slope of the regression line

ROA $=$ Return on Asset

$\mathrm{ROE}=$ Return on Equity

$\mathrm{e}=$ error term

\section{Results}

4.1 Level of Human Resource Accounting Disclosure

Table 1 presents the distribution of Human Resource reporting levels in terms of number of items disclosed as a 
percentage of the total disclosure items. The modal class of HR disclosure items 20 to $<40$ indicates that maximum of 33 companies' HR disclosure level Is 20 to $<40$ percent.

The table also shows that HRAD of around 63.46 percent of the sample companies are less than 40 percent of the disclosed items. The remaining 36.54 percent of the companies have HRADI "between ".40 to 60 percent. It implies that the level of human resource reporting of listed companies of Nigeria is very low.

Table 2. HR reporting levels

\begin{tabular}{lccc}
\hline & No of company & Company & Cumulative \\
\hline Score range & $(\mathrm{N})$ & $\%$ & $\%$ \\
$20 \%$ to $<40 \%$ & 33 & 63.46 & 63.46 \\
$40 \%$ to $<60 \%$ & 17 & 32.69 & 96.15 \\
$60 \%$ to $<80 \%$ & 2 & 3.85 & 100 \\
Total & 52 & 100 & \\
\hline
\end{tabular}

Source: Computed by the Researcher, 2012.

\subsection{Medium of Human Resource Accounting Reporting}

Table 2 shows that $57.41 \%$ of the total disclosed Human Resource Accounting Information is reported through Notes of annual reports and $16.73 \%$ is reported through Directors report. $11.41 \%$ of HRA information is reported in formal way through Profit and Loss accounts whereas $7.60 \%$ is disclosed in more informal way through Chairman's Report and $3.05 \%$ through profile of business.

Table 3. Medium of HRA reporting

\begin{tabular}{lcc}
\hline Medium of Reporting & Number of Information Reported & $\%$ \\
\hline Profit And Loss Amount & 30 & 11.41 \\
Notes & 151 & 57.41 \\
Director's Report & 44 & 16.73 \\
Managing Directors Report & 10 & 3.80 \\
Chairman's Report & 20 & 7.60 \\
Profile Of Business & 8 & 3.05 \\
Total & 263 & 100 \\
\hline
\end{tabular}

Source: Computed by the Researcher, 2012.

\section{Test of Hypotheses}

\subsection{Hypotheses One}

$\mathrm{HO}_{1}$ : There is no significant relationship between Return on Asset and Human Resource Accounting Disclosure".

The Relationship between Return on Asset and Human Resource Accounting Disclosure above shows that the correlation coefficient $(r)=-0.735^{*}$ (appendix 1). This value is high, implying that a strong relationship exist between Return on Asset and Human Resource Accounting Disclosure. The negative sign of the correlation value implies that an inverse relationship exist between them. The significant/probability value (PV) $=0.000<$ 0.05 level of significance therefore the researcher rejects the null hypothesis and accept the alternate.

$\mathrm{HO}_{2}$ : "There is no significant relationship between Return on Equity and Human Resource Accounting Disclosure".

The Relationship between Return on Equity and Human Resource Accounting Disclosure above shows that the correlation coefficient $(\mathrm{r})=0.893^{*}$ (appendix 2). This value is high, implying that a strong relationship exist between Return on Equity and Human Resource Accounting Disclosure. 
$\mathrm{HO}_{3}$ : There is no significant relationship between Financial Performance and Human Resource Accounting Disclosure".

The Relationship between Firm Financial Performance and Human Resource Accounting Disclosure above shows that the correlation coefficient $(\mathrm{r})=0.871^{*}$ (appendix 3). This value is high, implying that a strong relationship exist between Return on Equity and Human Resource Accounting Disclosure.

\section{Discussion and Conclusion}

The study suggests that an inverse relationship exists between the performance metrics (ROA) of a firm and its level of Human Resource Accounting Disclosure. This is not surprising because, return on assets (ROA) indicates a company's overall profitability. When investments on human capital development are expensed, the result will be that both assets and earnings will be understated. This will motivate companies with a low level of earnings to provide relevant information to investors and stakeholders regarding investment in human capital not reflected on the balance sheet.

Increase in return on Equity encourage firms in reporting human capital information so as to (1) establish trustworthiness with stakeholders and employ a valuable marketing tool(van der' Meer - Kovistra and Zijlstra, 2001; (2) enhance external reputation (Toms, 2002; Guthrie et al 2006). (3) appear legitimate in the public eye and avoid costs from non legitimacy (Deegan and Unerman, 2006; Beastie and Thomson, 2007).

Human Resource Accounting Information of an organization is very important factor to decision makers in an era of knowledge based economy. As a result, each organization takes serious attempt to disclose its HRA information to insiders and outsider decision makers. This is becoming an integral part of management report.

\section{Limitation}

An extensive effort was made to develop an accurate proxy for human Resource Accounting disclosure. There are some potential debates that the proxy selected may not be completely representative of a firm's human capital.

\section{Implications and Recommendation}

The findings in this study are also of considerable importance to both policy makers and firms. Given the view expressed by both academics and policy makers that the traditional financial reporting model fails to provide investors with value-relevant information, it may well be that in the future, the reporting of Human resource accounting information may be mandatory. Hence, the focus for policy should be to develop best practice guidelines for Human capital reporting and encourage compliance with such guidelines. Such an approach reduces problems of prescriptive guidelines which require enforcing.

Companies are receiving considerable encouragement to provide more information on the drivers of Human Resource accounting disclosure than ever before. There appears to be a trend to report beyond the limits of what traditional accounting standards require, and include a broader set of important value drivers.

After the study the following recommendations are made:

1) There should be a regulation in the accounting standard setting process for human capital reporting in Nigeria.

2) Standard should be created for human resource identification and measurement. This will enhance valuation of human capital, ensure a higher degree of utility to stakeholders, uniformity in disclosures and will allow a reliable comparison of human capital values.

3) Human Resource cost should be reported in asset accounts rather than as expenses.

4) A supplemental reporting in form of human capital statement is required to provide important information that traditional financial statement cannot capture. 


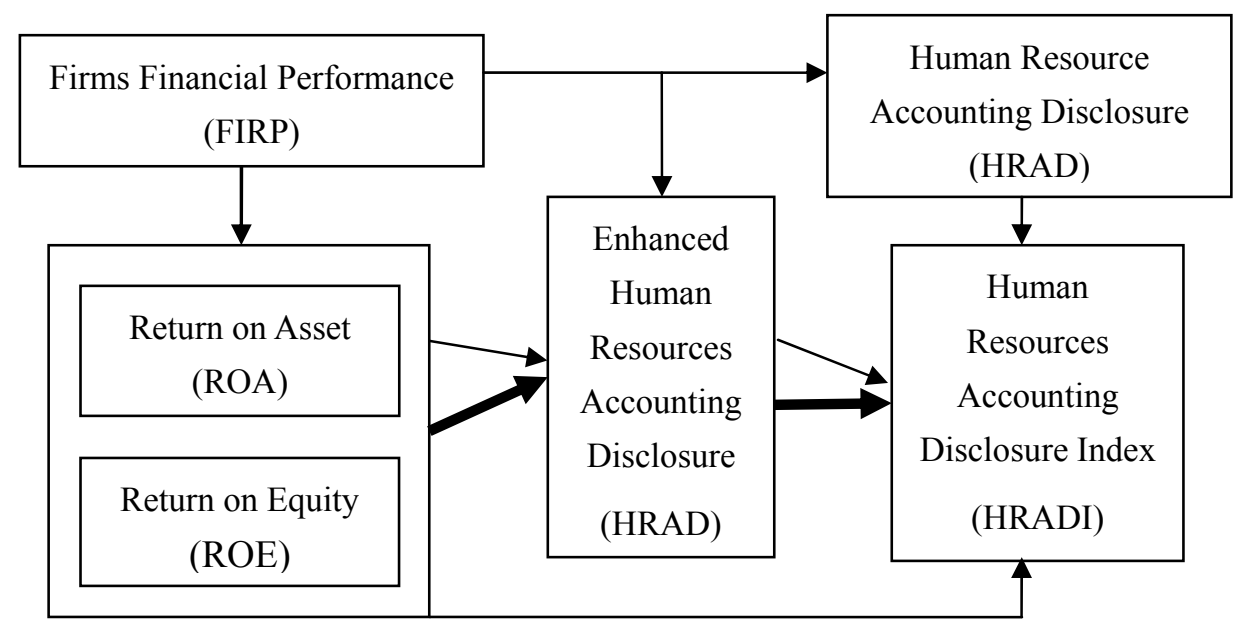

Figure 2. Findings

Bold Arrow: Strong and positive Relationship

Light Arrow: Negative Relationship

\section{References}

Ali, M. J., Ahmed, K., \& Henry D. (2004). Disclosure compliance with national accounting standards by listed companies in south Asia. Accounting and Business Research, 34(3), 183-199. http://dx.doi.org/10.1080/00014788.2004.9729963

Bassey E. B., \& Arzizeh T. T. (2012). Capitalized Human Resources Cost and its Influence on Corporate Productivity: A study of selected companies in Nigeria. International Journal of financial Research, 3(2).

Boedker, C., Mouristan, J., \& Guthrie, J. (2008). Enhanced business reporting: internationaltrends and possible policy directions. Journal of Human Resource Costing \& Accounting, 12(1), 14. http://dx.doi.org/10.1108/14013380810872734

Bullen, M. L. (2007). Human resource accounting: A useful tool for measurement and management in organizations. Leadership and Organizational Management Journal, 85-103.

Cascio, W. F. (1998). The future world of work : Implications for human resources Costing and accounting. Journal of Human Resource Costing and Accounting, 3(2), 9-19. http://dx.doi.org/10.1108/eb029045

Coff R. W. (1997). Human Assets and Management Dilemmas: Coping with Hazards on the Road to Resource Based theory. Academy of Management Review, 22(2), 374-402.

Davidove, E. A., \& Schroeder, P. A. (1992, August). Demonstrating ROI of training. Training and Development, 46(8), 70.

Dobija, M. (1998). How to place human resources into the balance sheet. Journal of Human Resource Costing \& Accounting, 3(1), 83-92. http://dx.doi.org/10.1108/eb029044

DMSTI. (2003 a, b). Analyzing Intellectual Capital statements. Danish Ministry of Science, Technology, and Innovation. Retreived from http://www.pnbukh.com/files/pdf_filer/Analysing_Intellectual_Capital_Statements.pdf

FASB. (2001). Improving business reporting: Insights unto enhancing voluntary disclosures. Retreived from http://www.fasb.org/cs/BlobServer?blobcol=urldata\&blobtable=MungoBlobs\&blobkey=id\&blobwhere=117 5819611134\&blobheader=application\%2Fpdf

Flamholtz, E. G., Bullen, M. L., \& Hua, W. (2002). Human Resource Accounting: A historical perspective and future implications. Management Decision, 40(10), 947-54. http://dx.doi.org/10.1108/00251740210452818

Grojer, J. E. (1997). Editorial. Journal of Human Resource Costing and Accounting, 2(2), 7-8.

Hedlin, P., \& Adolphson, J. (2000). Strategies for change in financial reports. Journal of Human Resource Costing and Accounting, 5(1), 27-35. http://dx.doi.org/10.1108/eb029061 
Hermanson, R. H. (1986). Accounting for Human assets. Research Monograph No. 99. Atlanta. Georgia: Business Publishing Division, College of Business Administration, Georgia State University.

International Accounting Standards Board. (2009). Retreived from www. iasb.org

Jones, G. (2000). Viewpoint: Accounting for people. Benefits Canada, 24(1), 9.

Salman R. T. (2011). Intellectual Capital Reporting in Nigeria: A Way Forward. Retreived from http://www.aibuma.org/abstract.php?value $=101$

Okwy P. O., \& Christopher C. O. (2010). Human Capital Accounting and Its relevance to stock investment Decisions in Nigeria. European Journal of Economics, Finance and Administrative Sciences, 21, 64-76.

Olsson, B. (2001). Annual reporting practices: information about human resources in corporate annual reports in major Swedish companies. Journal of Human Resource Costing and Accounting, 5(1).

Patra R., Khatik, S. K., \& Kolhe, M. (2003). Human resource accounting policies and practices: A case study of Bharat Heavy Electricals Limited, Phopal, India. International Journal of Human Resources Development and Management, 3(4), 285. http://dx.doi.org/10.1504/IJHRDM.2003.003407

Sveiby, K. E. (1997). The new organizational wealth. San Francisco: Berrett-Koehler.

Sonnier, K., \& Carson, C. P. (2007). Accounting for intellectual capital: The relationship between profitability and Disclosure. Journal of Applied Manager and Entrepreneurship, April.

Williams S. M. (2001). Is Intellectual Capital Performance and Disclosure Practices related? Journal of Intellectual Capital, 2(3), 192. http://dx.doi.org/10.1108/14691930110399932

\section{Appendix}

Appendix I. Correlation analysis showing the relationship between return on asset and human resource accounting disclosure

\begin{tabular}{lllrr}
\hline & & \multicolumn{2}{c}{ Correlations } & \\
\hline Type & Variables 1 & Statistics & $\begin{array}{c}\text { Human Resource } \\
\text { Accounting } \\
\text { Disclosure Index }\end{array}$ & $\begin{array}{c}\text { Return on } \\
\text { Asset }\end{array}$ \\
\hline Pearson's r & Human Resource Accounting & Correlation Coefficient & 1.000 & $-.735^{*}$ \\
& Disclosure Index & Sig. (2-tailed) &. & .000 \\
& & $\mathrm{~N}$ & 52 & 52 \\
& Return on Asset & Correlation Coefficient & $-.735^{*}$ & 1.000 \\
& & Sig. (2-tailed) & .000 & 52 \\
\hline
\end{tabular}

*. Correlation is significant at the 0.05 level (2-tailed)

Appendix II. Correlation analysis showing the relationship between return on equity and human resource accounting disclosure

\begin{tabular}{lllrr}
\hline Type & Variables 1 & Statistics & $\begin{array}{c}\text { Cuman Resource } \\
\text { Accounting } \\
\text { Disclosure Index }\end{array}$ & $\begin{array}{c}\text { Return on } \\
\text { Equity }\end{array}$ \\
\hline Pearson's r & Human Resource Accounting & Correlation Coefficient & 1.000 & $.893^{* *}$ \\
& Disclosure Index & Sig. (2-tailed) &. & .000 \\
& & $\mathrm{~N}$ & 52 & 52 \\
& Return on Equity & Correlation Coefficient & $.893^{* *}$ & 1.000 \\
& & Sig. (2-tailed) & .000 &. \\
& $\mathrm{~N}$ & 52 & 52 \\
\hline
\end{tabular}

**. Correlation is significant at the 0.01 level (2-tailed) 
Appendix III. Regression analysis showing the effects of return on asset and return on equity on human resource accounting disclosure

\begin{tabular}{llcc}
\hline & & Variables Entered/Removed & \\
\hline Model & Variables Entered & Variables Removed & Method \\
\hline 1 & Return on Equity & & Enter \\
& Return on Asset & & \\
\hline
\end{tabular}

a. All requested variables entered.

b. Dependent Variable: Human Resource Accounting Diclosure Index

\begin{tabular}{llccc}
\hline & & \multicolumn{3}{c}{ Model Summary } \\
\hline Model & $\mathrm{R}$ & R Square & Adjusted R Square & Std. Error of the Estimate \\
\hline 1 & $.871^{\mathrm{a}}$ & .759 & .709 & 10.87562 \\
\hline
\end{tabular}

a. Predictors: (Constant), Return on Equity, Return on Asset

\begin{tabular}{lllcccc}
\hline & \multicolumn{5}{c}{ ANOVA $^{\mathrm{b}}$} \\
\hline 1 & Model & Sum of Squares & df & Mean Square & F & Sig. \\
\hline & Regression & 847.143 & 2 & 423.571 & 3.581 & $.035^{\text {a }}$ \\
& Residual & 5795.681 & 49 & 118.279 & & \\
Total & 6642.824 & 51 & & & \\
\hline
\end{tabular}

a. Predictors: (Constant), Return on Equity, Return on Asset

b. Dependent Variable: Human Resource Accounting Diclosure Index

\begin{tabular}{|c|c|c|c|c|c|c|}
\hline \multicolumn{7}{|c|}{ Coefficients $^{\mathrm{a}}$} \\
\hline & \multirow[t]{2}{*}{ Model } & \multicolumn{2}{|c|}{ Unstandardized Coeeficients } & \multicolumn{3}{|c|}{ Standardized Coeeficients } \\
\hline & & $\mathrm{B}$ & Std. Error & Beta & $\mathrm{t}$ & Sig. \\
\hline \multirow[t]{3}{*}{$\overline{1}$} & (Constant) & 35.011 & 1.857 & & 18.855 & .000 \\
\hline & Return on Asset & -.432 & .166 & -.348 & -2.609 & .012 \\
\hline & Return on Equity & .810 & .003 & .789 & 6.667 & .000 \\
\hline
\end{tabular}

a. Dependent Variable: Human Resource Accounting Diclosure Index 